\title{
ASSESSMENT OF THE DYNAMICS AND FORECASTS OF MERGERS AND ACQUISITIONS IN THE BALTIC STATES
}

\author{
Kristina Garškaitè-Milvydienė \\ Department of Business Management, Vilnius Gediminas Technical University, Vilnius, Lithuania \\ E-mail: kristina.garskaite-milvydiene@vgtu.lt
}

Received 22 April 2020; accepted 06 May 2020

\begin{abstract}
In terms of corporate merger and acquisition (M\&A) deals, the year 2018 was an exceptional year for the Baltic States, with the highest number of deals in the region over the past few years. However, not only were their numbers increasing, but also their value, which increased compared to previous years. Based on the latest data available, the article analyses and forecasts the Baltic M\&A market and its trends. The main purpose of the paper is to ascertain the situation in the area of mergers and acquisitions, identify the sectors with the largest number of such deals and trends of mergers and acquisitions.
\end{abstract}

Keywords: mergers and acquisitions, deals, macroeconomy, economic sectors, economic development and growth.

JEL Classification: F63, G34, M21.

\section{Introduction}

In times of major economic change, mergers and acquisitions have become a common and frequent method of business development which is widely used in domestic transactions and transactions between geographically remote countries (Haleblian \& Devers, 2009; Choi \& Jeon, 2011; Brigham \& Daves, 2012). Global growth in the value and number of merger and acquisition deals inevitably changes not only the activities of the enterprises involved in the deals but also the industrial and economic landscape of the countries (Adams, 2008; Agrawal \& Knoeber, 2012; Deng et al., 2013).

An enterprise that uses strategic planning to ensure its survival constantly faces the challenge of promoting growth externally or using internal resources to grow (Campbell et al., 2008; Roman \& Rusu, 2011; Adam \& Jacob, 2012; Kotane \& Kuzmina-Merlino, 2012). External development is related to business mergers and acquisition (M\&A) (Fraser \& Zhang, 2009; Gaughan, 2015). Consideration of this challenge is an ongoing process. Many enterprises merge to expand their activities and to diversify their risks (Parikh, 2011; Wang \& Xie, 2009). It is also essential to assess the strategic and organisational competencies of merging enterprises. Acquisition of strategic and organisational competences in a merger can ensure growth and competitive advantage for an enterprise, increase productivity, boost turnover and profitability, and improve management efficiency (Rossi et al., 2004; Lin et al., 2008; De Pamphilis, 2010; Gaughan, 2015).

There exist various reasons why enterprises merge or acquire each other (Kolasa, 2008; Doytch \& Cakan, 2011). Corporate mergers or acquisitions are generally more frequent under good economic conditions, with the expectation of a future which, if not better, would at least be no worse than the present (Baliamoune-Lutz, 2004; Maček \& Ovin, 2006; Maček, 2012). It is expected that the corporate mergers and acquisitions can help to acquire new technological capabilities, promote an enterprise's trademark, bring about various synergies, economies of scale and management, achieve better allocation of resources, market power gains and many more goals (Tsang \& Hauck, 2007; Cornett et al., 2006; Parikh, 2011). However, several key aspects need to be considered right from the start and potential surprises need to be prepared for successful completion of the merger or acquisition process.

The number of strategic corporate mergers and acquisitions worldwide is constantly increasing, the experience of this process shows that such a growth strategy is not only successful but also unsuccessful: merged enterprises fail to reap the expected benefits, business value and profitability decline, qualified workers are lost (Lin et al., 2006; Uddin \& Boateng, 2011). However, scientists and practitioners argue that corporate mergers and acquisitions do bring financial benefits. For some enterprises participating in merger and acquisition 
markets, such deals can ensure long-term success, and for the persons who successfully lead the implementation of this process, it can be a milestone in their entire careers (M. R. Edwards \& T. Edwards, 2013; Milichovsky \& Simberova, 2015).

Thus, the topic of mergers and acquisitions is becoming the subject of research among the growing number of researchers from different disciplines around the world. Recently, the amount of global investments directed towards the implementation of merger processes has increased significantly (Mottaleb, 2007; Gruodis, 2009; Bevins et al., 2010; Baltic M\&A Monitor, 2019; M\&A worldwide, 2019). The practical significance of mergers has increased, both strategically and financially. The authors from different disciplines who have analysed motives behind corporate mergers threat the mergers and their influence on the future activities of an enterprise very variously within the scope of their research interests. In analysing the merger processes, some financial professionals focus on shareholder value (Cornett et al., 2006; Bazar \& Sakar, 2011; Burkart et al., 2012). An analysis of other studies has found that a merger does not always promote an enterprise's value growth considering both short- and long-term indicators of the enterprise (Fraser \& Zhang, 2009; Agrawal \& Knoeber, 2012), while some authors have argued that mergers can even lower the value of the enterprise being acquired and affect the volatility of profits (Chatterjee, 2007; Campbell et al., 2008). The activity in the merger and acquisition market is often linked to various macroeconomic indicators (Neto et al., 2008; De Pamphilis, 2010; Gaughan, 2015).

For the Baltic States, the year 2018 was an exceptional year with regards to corporate merger and acquisition (M\&A) deals, as "Mergermarket" recorded the highest number of such deals in the region (Baltic M\&A Monitor, 2019; M\&A Worldwide, 2019; Versli Lietuva, 2019). However, not only were their numbers increasing, but also their value, which increased compared to previous years. Gross domestic product growth in all three Baltic States, falling unemployment and rising consumption contributed to a spurt in the region's merger and acquisition market.

This paper looks at corporate merger and acquisition deals and their trends. The main aim of the paper is to find out what is the situation with the merger and acquisition deals, in which areas they are most numerous, and what are the future trends of mergers and acquisitions in the three Baltic States.
Research methods: systemic, comparative and logical analysis of scientific and practical articles.

\section{Analysis of mergers and acquisitions in the Baltic States}

The merger and acquisition trends observed in recent years in the three Baltic States, namely, Estonia, Latvia and Lithuania, have been on the rise (Baltic M\&A Monitor, 2019). Despite the unstable international environment, statistical data show that the year 2018 was a record year for the region. A US-based private equity fund, the Blackstone Group (2019), acquired a majority stake in the bank Luminor. It was one of the largest deals in the region in the last decade, and so was also a great achievement for a relatively small market. Corporate mergers and acquisitions in the Baltic region are taking place also at the international level, where enterprises and funds from Scandinavian countries are particularly active and the geographical range of investors is expanding. The Blackstone Group deal (the Baltic bank Luminor) demonstrates the increasing US interest in the Baltic countries, while investors from China and the United Kingdom have recently taken part in increasingly high-value deals.

Particularly many deals were signed in 2017 2018 in the Technology, Media and Telecommunications (TMT) sector. The large number of M\&A offers in the sector indicates that the Baltic region of interest for investors because of its considerable technological capacity (Baltic M\&A Monitor, 2019; M\&A Worldwide, 2019; Versli Lietuva, 2019). Internationally renowned names, such as Skype, TransferWise and Taxify, have linked their operations with the Baltic States, making it a global technology development opportunity for the Baltic States. Multinational companies are coming to the region to acquire excellent intellectual property.

The M\&A activity was particularly strong in the Baltic States with 74 deals for EUR 2.7 billion, which shows a growth rate of $43 \%$ and $320 \%$ respectively as compared to 2017 (Figures 1,2) (Baltic M\&A Monitor, 2019; M\&A Worldwide, 2019; Versli Lietuva, 2019).

The volume of deals increased the most in Estonia and accounted for $43 \%$ of all deals in the Baltic region in 2018 (Baltic M\&A Monitor, 2019; M\&A Worldwide, 2019; Versli Lietuva, 2019). This shows that Estonia is one of the most open countries and that its technology sector has reached the international level since independence. It is in this country that the highest value deals were con- 
cluded: the value of the deals made up just over EUR 2 billion. US-based private equity fund Blackstone Group (2019) acquired for EUR 1 billion a $60 \%$ stake in the banking company Luminor Group (2019).

The number of deals in Lithuania doubled (25 deals were signed), accounting for more than one third $(34 \%)$ of all deals in the region compared to 2017. In Latvia, the volume of M\&A deals amounted to $23 \%$. The value of the deals rose to EUR 394 million, although in 2015 the value of deals averaged EUR 426 million (Figure 2) (Baltic M\&A Monitor, 2019; M\&A Worldwide, 2019).

The increasing development of M\&A in the Baltic region in recent years demonstrates the interest of international investors. In 2018, 55\% of deals were signed with foreign countries, which is relatively similar to 2017 (59\%) (Baltic M\&A Monitor, 2019). In contrast to previous years, cross-border M\&A deals currently represent well over half of the total volume of deals compared to 2012, when such deals accounted for only $37 \%$. Due to the region's competitive advantage, international and domestic investment and other funds are becoming increasingly active in the region. This trend is expected to continue in 2019, especially in the technology and manufacturing sectors (Figure 3).

However, despite a strong upward trend 2018 year, the year 2019 has been marked by global failures, including Brexit uncertainty about the euro area and trade tensions between the US and China, which can affect mergers and acquisitions across regions (Golbe \& White, 2000; Baltic M\&A Monitor, 2019; M\&A Worldwide, 2019; Versli Lietuva, 2019).

The upcoming end of the current economic cycle in Europe might lead to slower growth of the Baltic economies in 2019 and 2020 (Baltic M\&A Monitor, 2019).

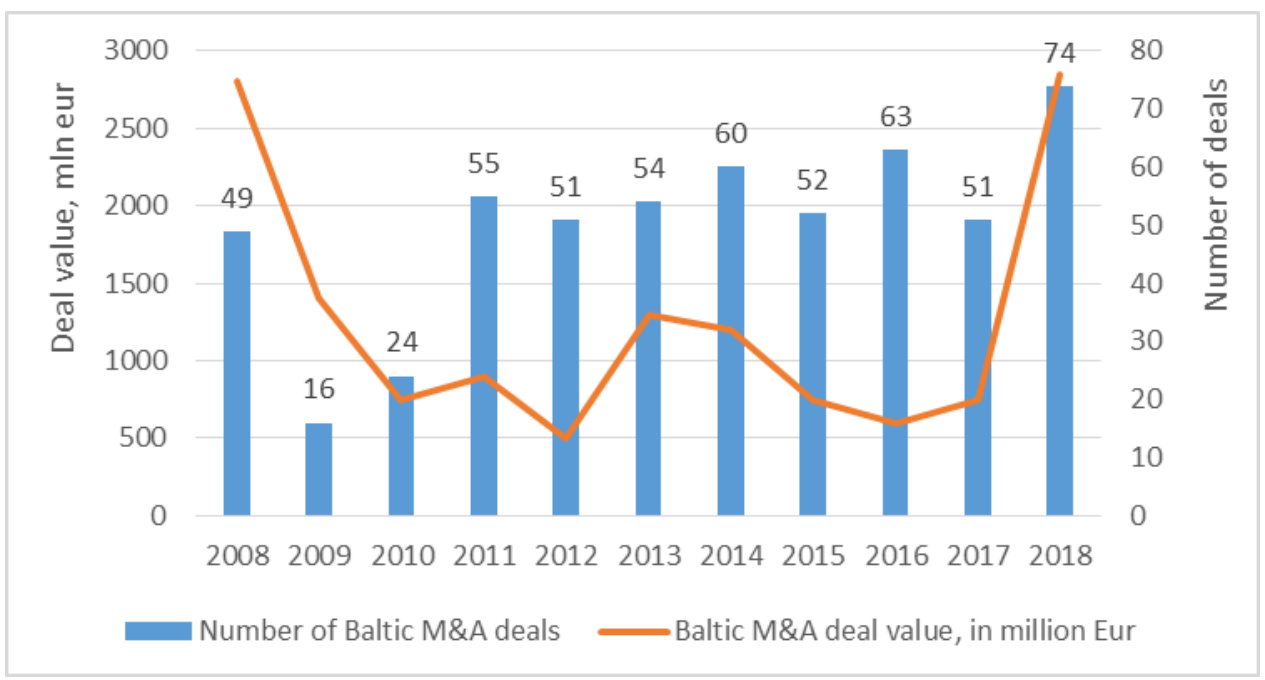

Figure 1. Baltic M\&A (source: developed by the authors based on Baltic M\&A Monitor, 2019)

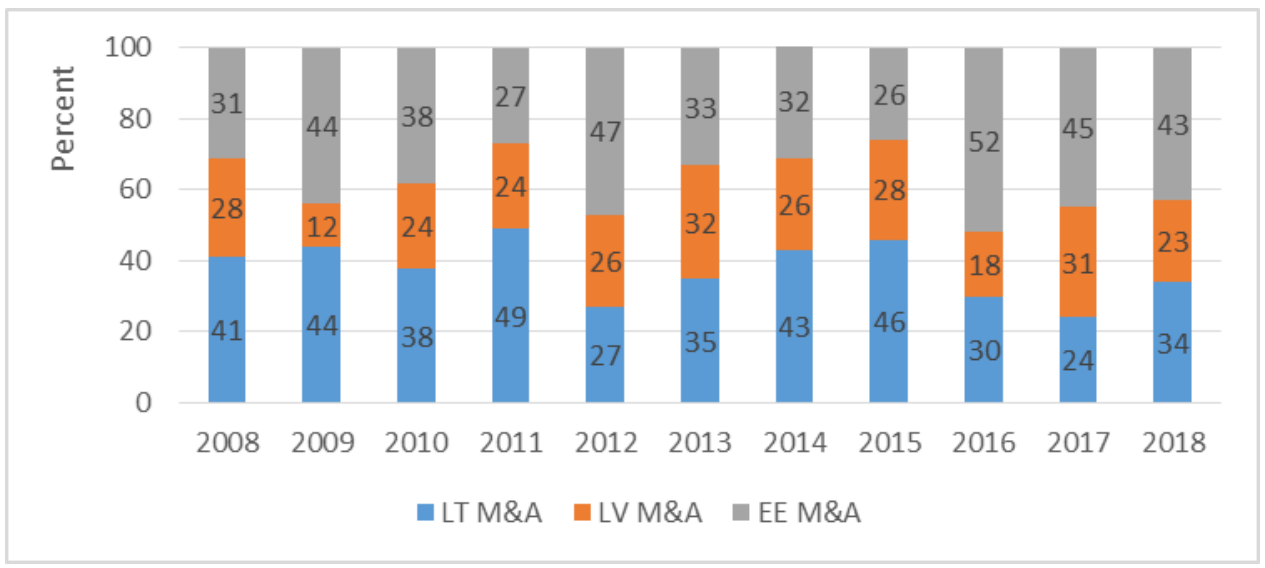

Figure 2. Baltic M\&A deal volume by country (source: developed by the authors based on Baltic M\&A Monitor, 2019) 


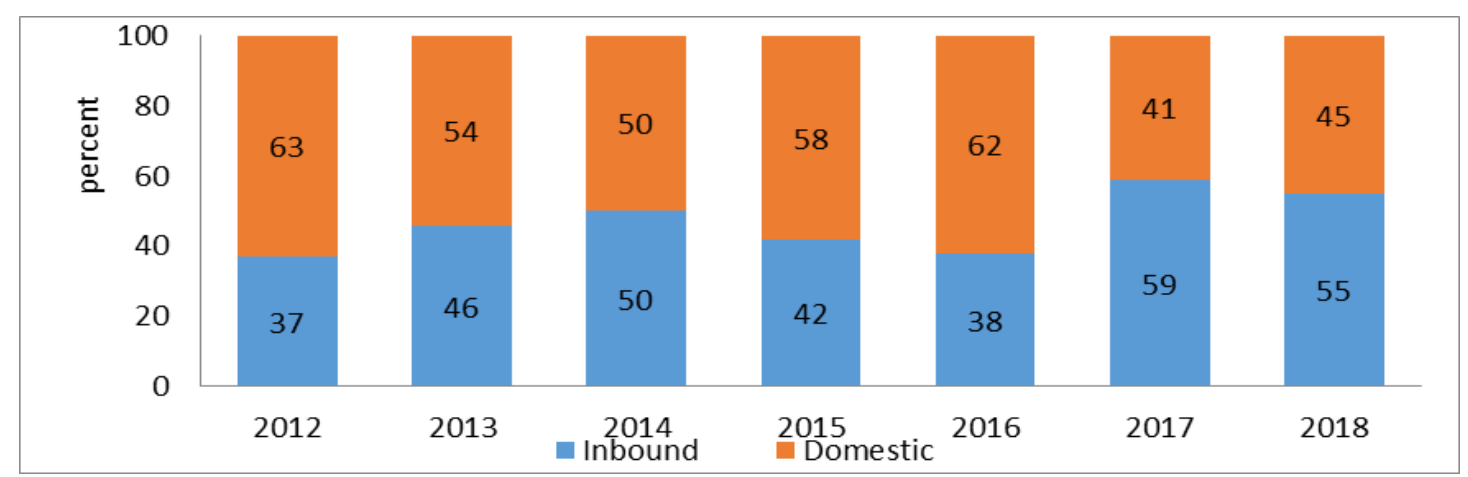

Figure 3. The volume of inbound and domestic M\&A deals (source: developed by the authors based on Baltic M\&A Monitor, 2019)

However, despite the unresolved global situation, there can still be found the reasons why the trends and prospects for corporate mergers and acquisitions in the Baltic States are increasing (Rhodes-Kropf \& Viswanathan, 2004). The sustainability of assets available on the market in the Baltic States will continue to attract both foreign strategies and sponsors, investors (Alfaro et al., 2004; Calderon et al., 2004). Currently, Estonia, Latvia and Lithuania are among the most competitive economies in Europe in terms of regulation, taxation and costs.

\section{Sectoral analysis with regards to mergers and acquisitions in the Baltic States}

The volume and variety of deals demonstrate the strength of the M\&A market of the Baltic States, though some sectors have typically been more active than others. In 2018, US-based PE (private equity) fund Blackstone acquired a majority stake in the Baltic regional bank Luminor. This not only highlighted the overall strength of enterprises in the region and the confidence of investors but also reflected the ongoing consolidation of the regional financial sector. Meanwhile, the technology sector remains the most active, especially in terms of volume of deals. The economic and financial sector also appears to be rapidly growing.

The Technology, Media and Telecommunications (TMT) sector remain the leading and most active sector in the region with regards to deals. In 2017-2018, TMT accounted for $17 \%$ of the total volume of deals, i.e., more than any other industry (Baltic M\&A Monitor, 2019; M\&A Worldwide, 2019; Versli Lietuva, 2019). However, the majority of these deals were relatively small in value, and the sector accounted for only $9 \%$ of the total value of deals (Figures 4, 5).

The regional technology sector benefits from the long-standing successful tradition of technical education in the Baltic States, as well as from government efforts to create a favourable business environment for growth and investment. According to data of the technology sector, Lithuania is one of the largest European countries in attracting investments in financial technology (fintech) (Baltic M\&A Monitor, 2019).

Last year was rather difficult for the Bank of Lithuania in seeking to become a fintech centre in Central and Eastern Europe. The main and strategic objective of the Bank of Lithuania remains unchanged, and from 2019 onwards, the bank is becoming increasingly selective towards investors. The Bank of Lithuania intends to apply stricter criteria to investors and to issue licences only to those participants who are of good repute or whose investments benefit the State of Lithuania and create new jobs. Lithuania seeks to ensure that the financial sector would be highly rated in Europe and globally.

Latvia also had several deals in the TMT sector (Baltic M\&A Monitor, 2019; M\&A Worldwide, 2019; Versli Lietuva, 2019). This proves the strength of the Latvian technology industry, as the deals were signed to expand the country's resources and base of knowledge.

The Financial Services sector accounted for $7 \%$ of total deal volume during 2017-2018. The total value of deals increased from $6 \%$ in 20152016 up to $30 \%$ in the last two years, including the Blackstone/Luminor deal (Figures 4, 5) (Baltic M\&A Monitor, 2019). Luminor is a group of banks operating in all three Baltic States and formed in 2017 by merging a Danish bank, Nordea, and a Norwegian partner, DNB. The deal is one of the largest in the Baltics and, according to Luminor, the bank will be able to expand its next-generation services. The Luminor deal benefits the Baltic banking sector. US investments in the sector, which is dominated by Scandinavian banks, infuse greater dynamism into the Baltic banking market. 


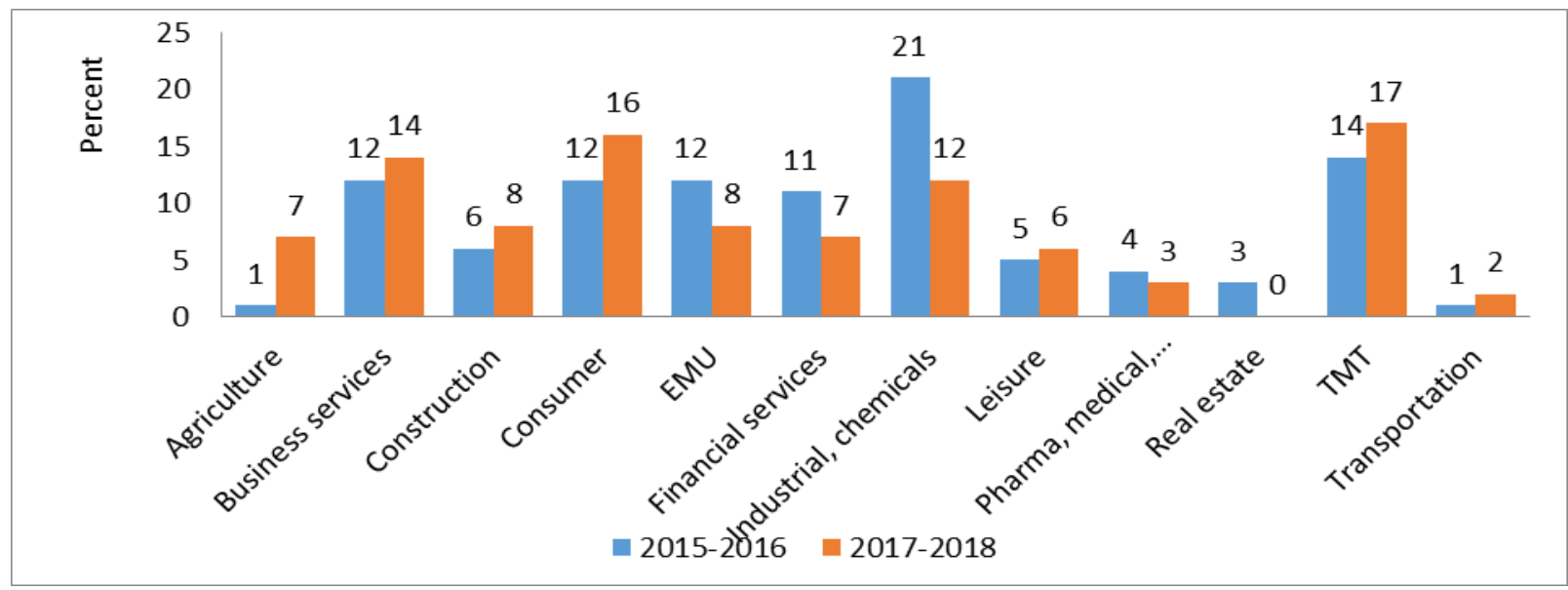

Figure 4. Baltic M\&A deal volume by sector (source: developed by the authors based on Baltic M\&A Monitor, 2019)

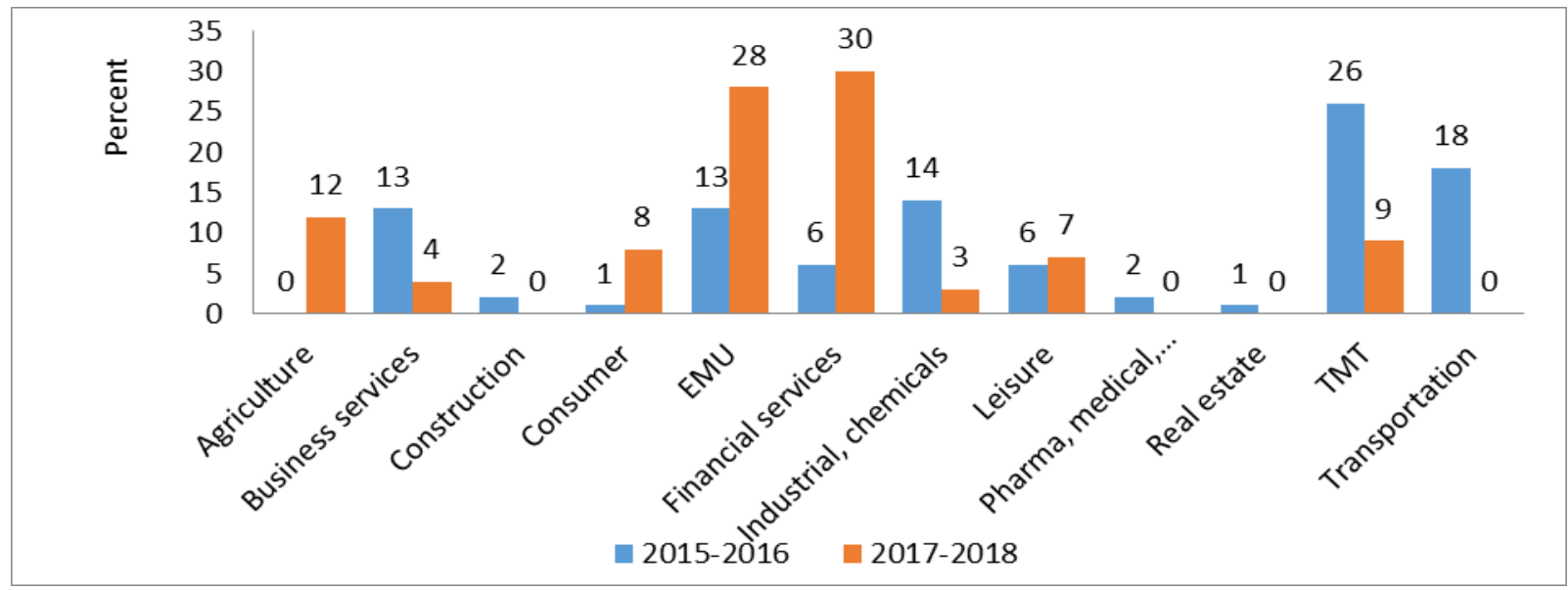

Figure 5. Baltic M\&A deal value by sector (source: developed by the authors based on Baltic M\&A Monitor, 2019)

In recent years, macro-regional consolidation has been a major driver of corporate (banks) mergers and acquisitions in the financial sector of the Baltic States, leading to competition, costs and regulatory pressures. This sector has also been affected by money laundering scandals in certain banks. While it is not a systemic issue, a clean-up may lead to further consolidation over the medium term and regulatory changes that will affect the financial market. These changes have prompted the Baltic States to tighten up regulation of the banking sector. This may have some impact on M\&A activities.

The Energy, Mining and Utilities (EMU) sector has been relatively active in recent years as a result of efforts to diversify energy resources and to restructure the utility sector, although the Baltic States are not particularly rich in natural resources. In 2017-2018, this sector accounted for $8 \%$ of the volume of mergers and acquisitions, with the total value increasing significantly from $13 \%$ to $28 \%$
(Figures 4, 5) (Baltic M\&A Monitor, 2019). The increase in value was driven by several large-scale deals, both inbound and domestic.

The region's Consumer (Trade) sector accounted in 2015-2016 for $11 \%$ of the total volume of deals but only $1 \%$ of their total value. In 2017 2018 , it increased to $16 \%$ and $7 \%$, respectively (Figures 4, 5) (Baltic M\&A Monitor, 2019; M\&A Worldwide, 2019). The sector is characterised by relatively high purchasing power and growth, which is generally above the EU average despite the relatively small size of the markets.

Over the past two decades, international investors have shown strong interest in the Baltic consumer market owing to revenue growth and increasing demand for retail trade in modern commodities. Although Chinese investments in the Baltics have not been as significant as in other Central and Eastern European countries, the consumer industry has been an exception, since investors have hoped to make use of the range of Baltic 
products and experience of producers to expand the Chinese market. However, this sector is facing considerable risks. The relatively small and open economies of the Baltic States are sensitive to changes in the world and the European economy. One example, a renewed euro area crisis or EU recession would have a significant negative impact. The decline in the population of all three countries since the restoration of their independence also has some impact. The Baltic States are described as emerging markets with negative demographic trends.

Industrials and Chemicals sector. Although the economies of the three Baltic States are dominated by service sectors, the industry also occupies in the economies a prominent position based on historical legacy and the rapid development of technology and foreign direct investment over the last three decades. The Industrials and Chemicals sector has been characterised by smaller-scale deals in recent years. In 2017-2018, deals in this sector accounted for $12 \%$ of the total volume of deals and $3 \%$ of their total value, though decreased from $21 \%$ and $14 \%$ respectively compared to 2015-2016 (Figures 4, 5) (Baltic M\&A Monitor, 2019).

Private equity (PE) is playing an increasingly important role in the activities of M\&A in the Baltic States, as regional markets are becoming attractive. The number of regional enterprises has grown over the past three decades to the extent that they have become suitable for PE acquisitions (Figure 6) (Baltic M\&A Monitor, 2019; M\&A Worldwide, 2019). Meanwhile, international PE has become increasingly ambitious in searching for new targets and seeking to gain new markets. The development of the Baltic markets has also led to the emergence of regional PE funds (Figure 6) (Baltic M\&A Monitor, 2019; M\&A Worldwide, 2019).

The largest deal in 2018 with the participation of PE was the acquisition by Blackstone of $60 \%$ of shares in Luminor. German, Polish PE and venture capital funds are also among those looking for transaction opportunities in the Baltic States (Baltic M\&A Monitor, 2019; M\&A Worldwide, 2019).

There are doubts that the relatively small size of the Baltic markets may be a barrier to international PE investors, given the relative size of their target. As a result, this market is not attractive enough for Scandinavian and Polish PE funds. Most of the deals have been signed by local PE funds. Thus, Polish and Scandinavian funds are expected to come, as only enterprises with a higher value or appropriate characteristics attract investors.

\section{Forecasting mergers and acquisitions in the Baltic States}

While overall economic growth is projected to slow down in 2019 and the global environment to pose a greater risk, the dynamic prospects of the Baltic States are quite good. The increase in investments in 2018 shows the strength and attractiveness of the region's market as well as the interest of large global investors. The Blackstone deal, in particular, demonstrates that the Baltic States are the focus of attention for truly large international investors (Baltic M\&A Monitor, 2019; M\&A Worldwide, 2019; Versli Lietuva, 2019).

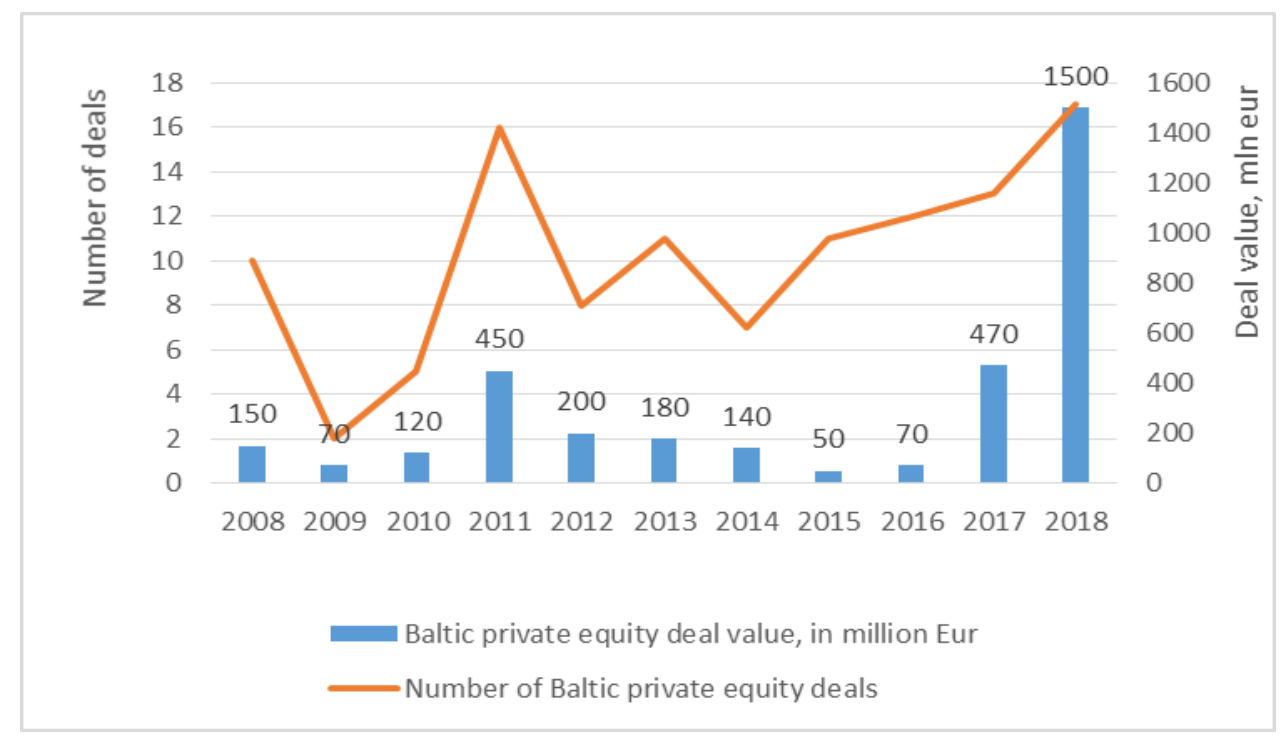

Figure 6. Baltic private equity during 2008-2018 (source: developed by the authors based on Baltic M\&A Monitor, 2019) 
The Industrials and Chemicals sector also saw large numbers of deals last year, however, growth rates in this area are slowing down due to global economic slowdown. On the opposite, the consumer and business services segments are among the fastest. This sector, too, is expected to become more active due to tighter regulation of the financial sector and the liquidation of unreliable banks.

Latvia is expected to have the highest growth rates and its GDP is projected to increase by $3.2 \%$ compared to $2.8 \%$ in Lithuania and Estonia (Baltic M\&A Monitor, 2019; M\&A Worldwide, 2019). Rising global trade and economic tensions, the complicated Brexit situation and other challenges faced by the euro area pose a risk. Geopolitical tensions between the West and Russia also cause concern. However, the three countries of the Baltic region have achieved excellent macroeconomic and political stability and a favourable business environment. The Baltic States are euro-area countries, strongly integrated into the EU, with growth rates well above average. Despite the small size of the local markets, enterprises in the region have also shown an excellent capacity to innovate and to compete globally. These are emerging markets with good growth rates (Baltic M\&A Monitor,
2019; M\&A Worldwide, 2019; Versli Lietuva, 2019).

To observe the future trends of factors under consideration, forecasts of mergers and acquisitions (in percentage) and foreign direct investment in the Baltic States are carried out. Forecasts of mergers and acquisitions in the Baltic States using the weighted moving average method reveal that the highest percentage of all mergers and acquisitions is in Estonia, lower - in Lithuania and the lowest - in Latvia (Figure 7). Figure 7 shows that no significant future fluctuations in the area of mergers and acquisitions in the Baltic States are expected according to the weighted moving average method.

The forecasts of another important factor, namely, foreign direct investment (FDI), in the Baltic States using the weighted moving average method show that Estonia's FDI has the highest value among all FDI in the Baltic States, while Lithuania's FDI has a lower value and Latvia's FDI has the lowest value (Figure 8). Figure 8 shows that no significant fluctuations in foreign direct investment in the Baltic States are projected in the future according to the weighted average moving method.

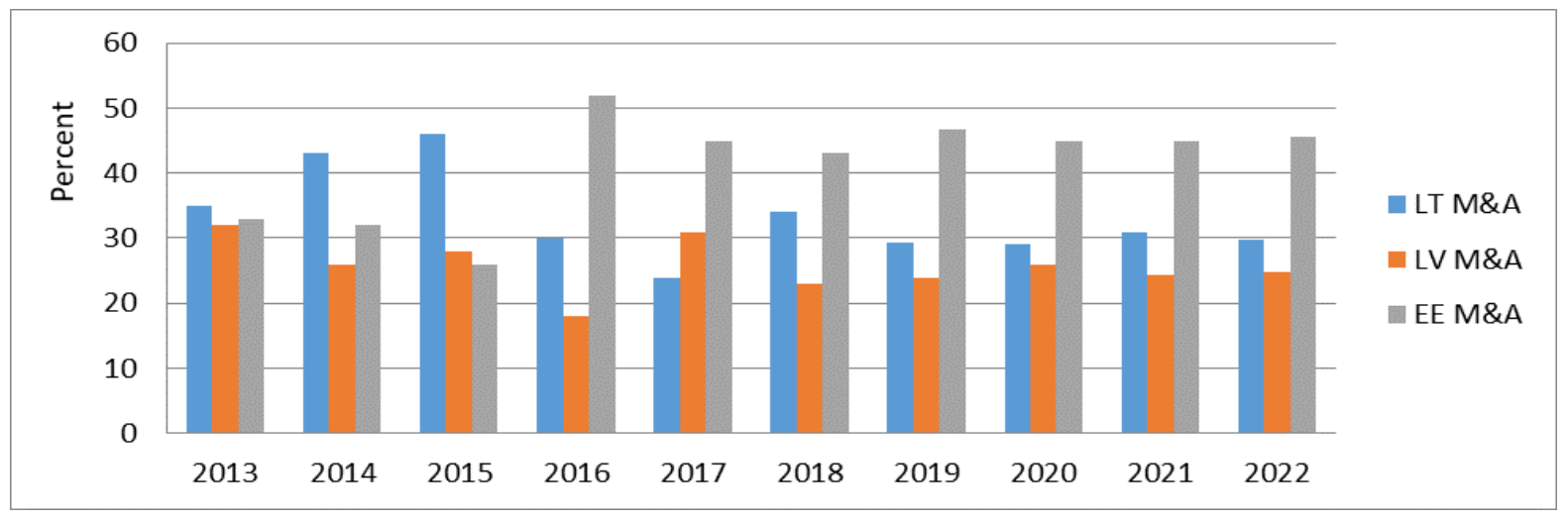

Figure 7. Forecast of mergers and acquisitions according to the weighted moving average method (source: developed by the authors based on Baltic M\&A Monitor, 2019)

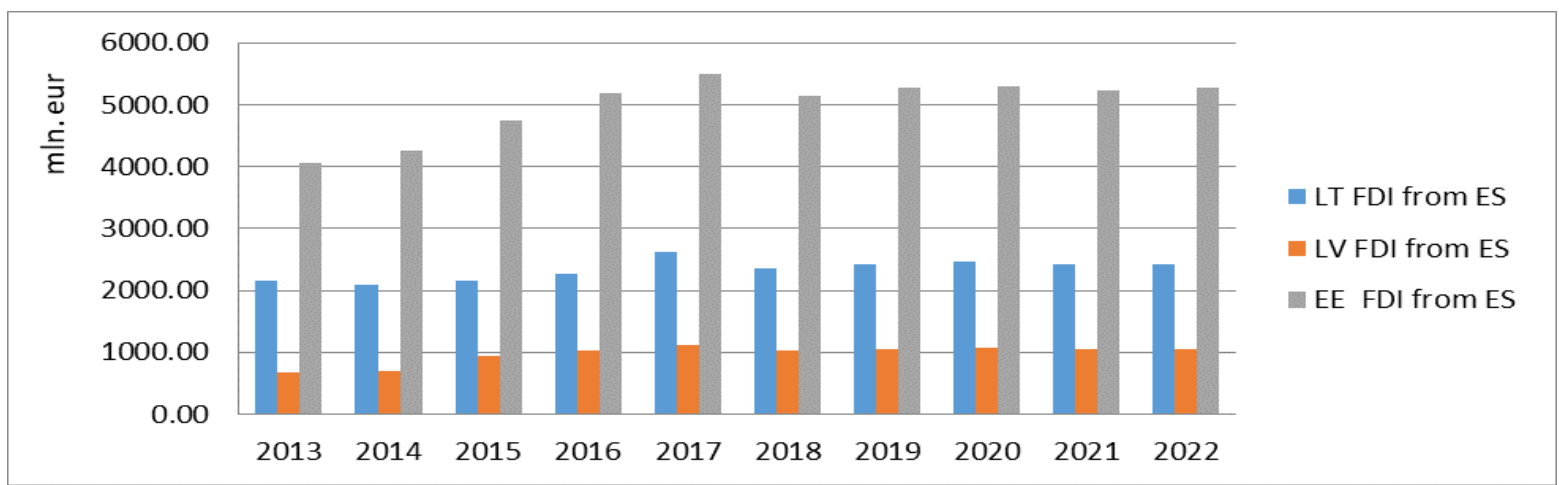

Figure 8. Forecast of direct foreign investment according to the weighted moving average method (source: developed by the authors based on Baltic M\&A Monitor, 2019) 
More detailed forecasting of the situation in Lithuania was further carried out according to the binary regression method, using the indicator of $\mathrm{M} \& \mathrm{~A}$ as the independent variable $\mathrm{Y}$ and other macroeconomic indicators as the dependent variables X (Figure 9). The following macroeconomic indicators were used: foreign direct investment, gross domestic product, inflation, unemployment. Figure 9 shows that the volume of mergers and acquisitions will increase slightly in the future in terms of GDP, but is expected to decline slightly according to a linear function. As regards inflation rates, the volume of mergers and acquisitions will fluctuate insignificantly in the future but is expected to decline slightly according to a linear function. The volume of mergers and acquisitions in terms of FDI will fluctuate slightly in the future, however, is expected to decline modestly according to a linear function.
Mergers and acquisitions in the Baltics were forecasted by applying various functions, such as exponential, linear, logarithmic, polynomial, power, etc. Upon analysing the outcomes of mergers and acquisitions in Lithuania and their graphs according to various functions, the function with the highest coefficient of determination and thus the correlation coefficient, i.e. $R^{2}=0.2432$, was selected for forecasting purposes (Figure 10). An analysis of the trends in mergers and acquisitions in Lithuania forecasted by applying a polynomial function shows that the percentage of these deals is to decrease significantly in the future. A forecast using the weighted moving average method also projects a downward trend in the future, though less marked.

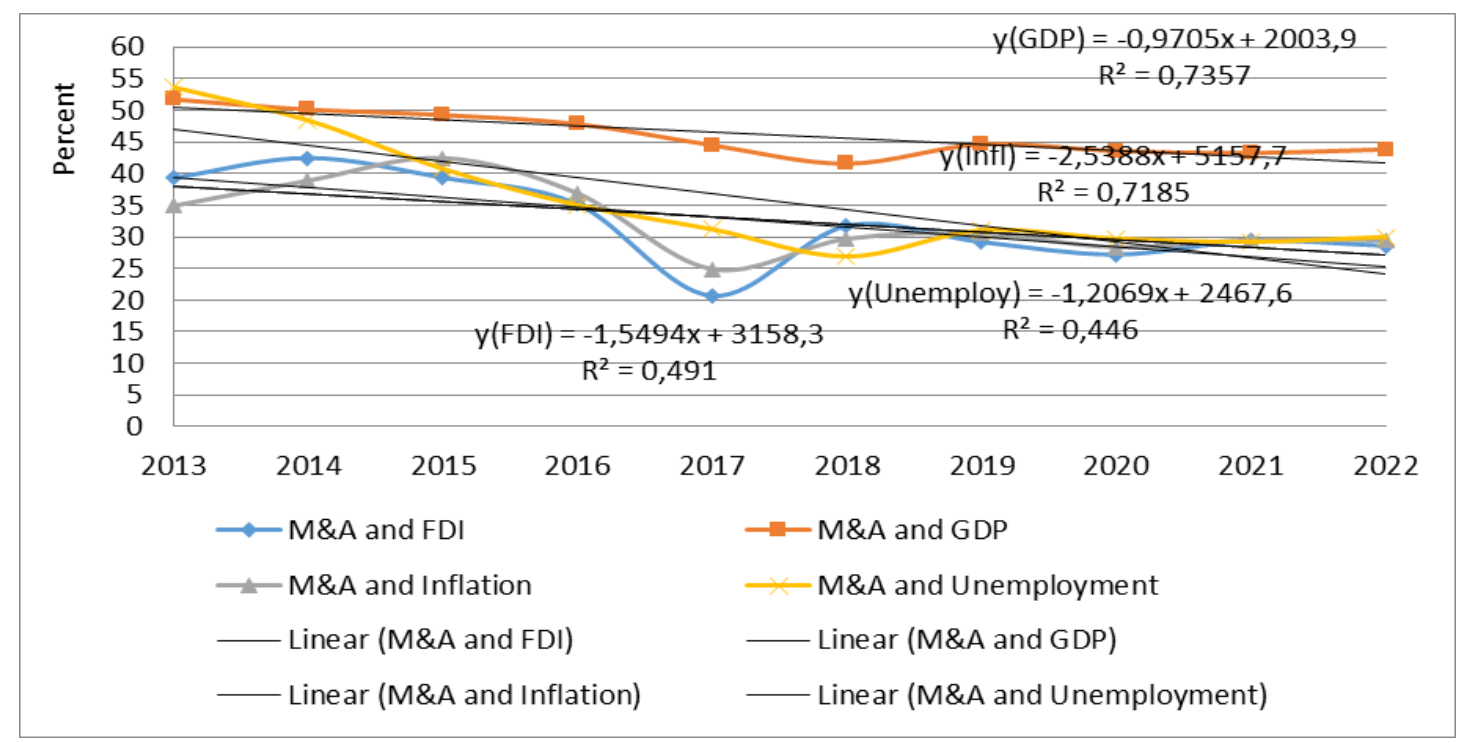

Figure 9. Forecast of mergers and acquisitions using binary regression equations (source: developed by the authors based on Baltic M\&A Monitor, 2019)

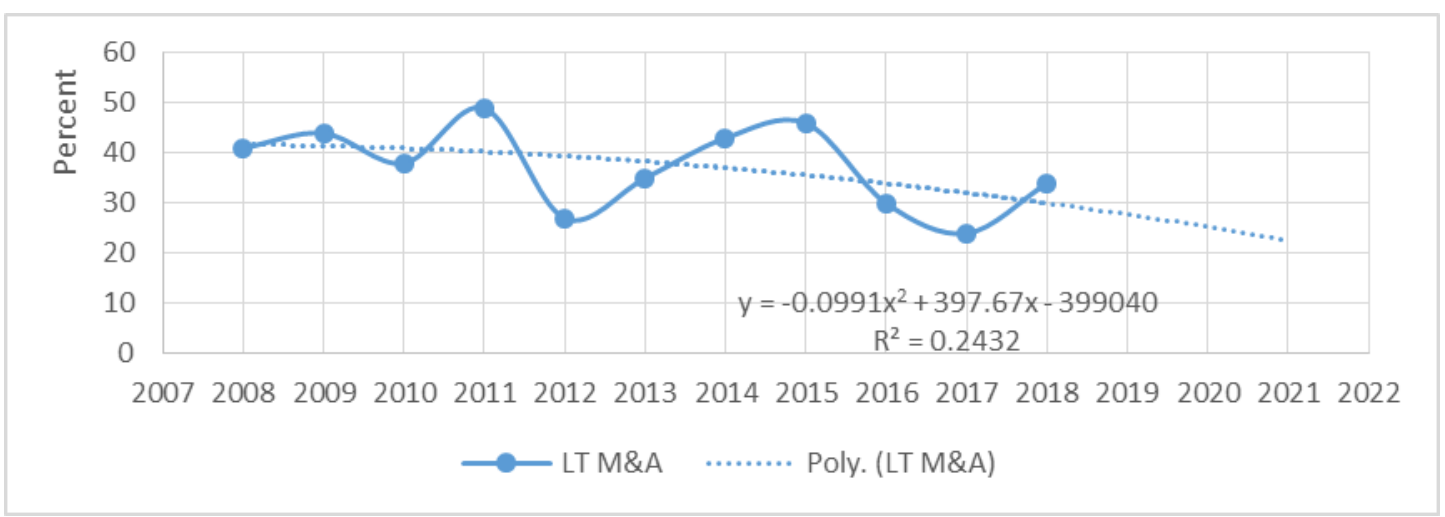

Figure 10. Forecast of mergers and acquisitions in Lithuania applying a polynomial function (source: developed by the authors based on Baltic M\&A Monitor, 2019) 
Mergers and acquisitions in Latvia were forecasted using various functions, such as exponential, linear, logarithmic, polynomial, power, etc. Upon analysing the outcomes and graphs of mergers and acquisitions in Latvia according to various functions, the function with the highest coefficient of determination, and thus the correlation coefficient, i.e. $R^{2}=0.0969$, was selected for forecasting purposes (Figure 11). An analysis of the trends in mergers and acquisitions in Latvia forecasted by applying a polynomial function reveals a marked decline in the percentage of these deals in the future. A forecast using the weighted moving average method also projects a downward trend in the future, though less marked.

Mergers and acquisitions in Estonia were forecasted using various functions, such as exponential, linear, logarithmic, polynomial, power, etc. Upon analysing the outcomes of the mergers and acquisitions in Estonia and their graphs according to various functions, the function with the highest coefficient of determination and thus the correlation coefficient, i.e. $R^{2}=0.1527$, was selected for forecasting purposes (Figure 12). An analysis of the trends in mergers and acquisitions in Estonia forecasted by applying a polynomial function forecasts a significant increase in the percentage of these deals in the future. A forecast using the weighted moving average method also predicts an upward trend in the future, though less marked.

To examine in more detail the dynamics and expected trends of mergers and acquisitions in the Baltic States, they were forecasted using the weighted moving average method and applying various functions (exponential, linear, logarithmic, polynomial, power, etc.). Merger and acquisition forecasting using the weighted moving average method and its various functions shows that in the foreseen period, the number of mergers and acquisitions will be the highest in Estonia, being smaller in Lithuania and the smallest in Latvia. These trends do not project major changes in the future.

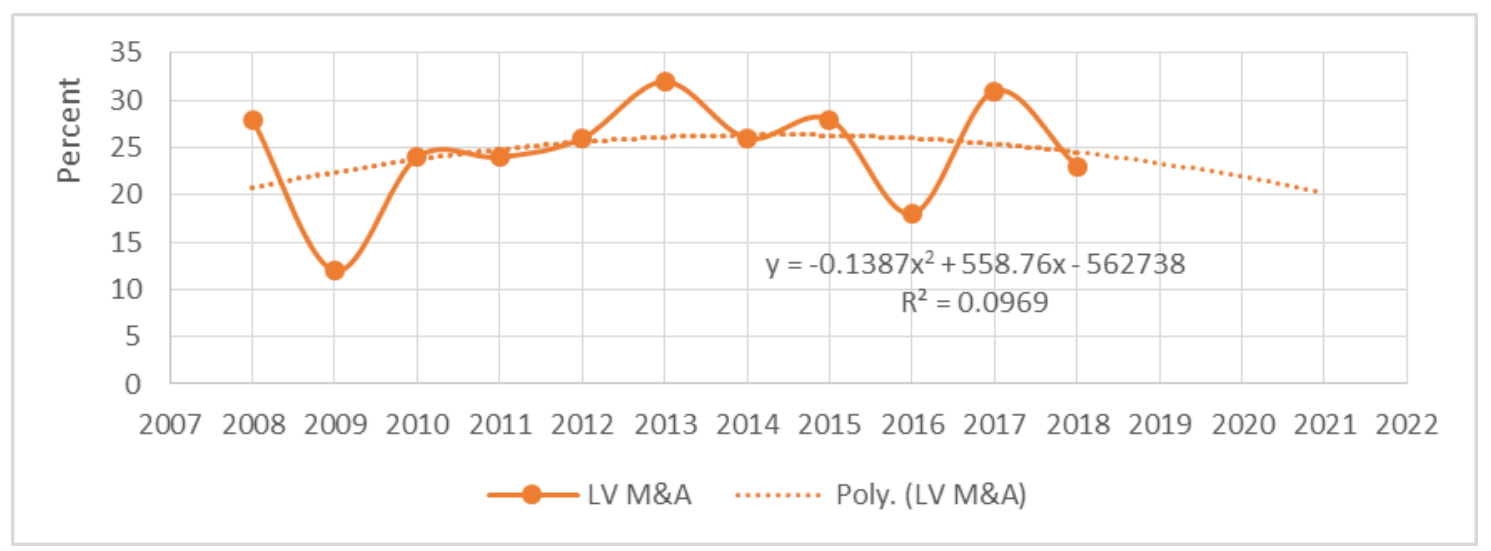

Figure 11. Forecast of mergers and acquisitions in Latvia applying a polynomial function (source: developed by the authors based on Baltic M\&A Monitor, 2019)

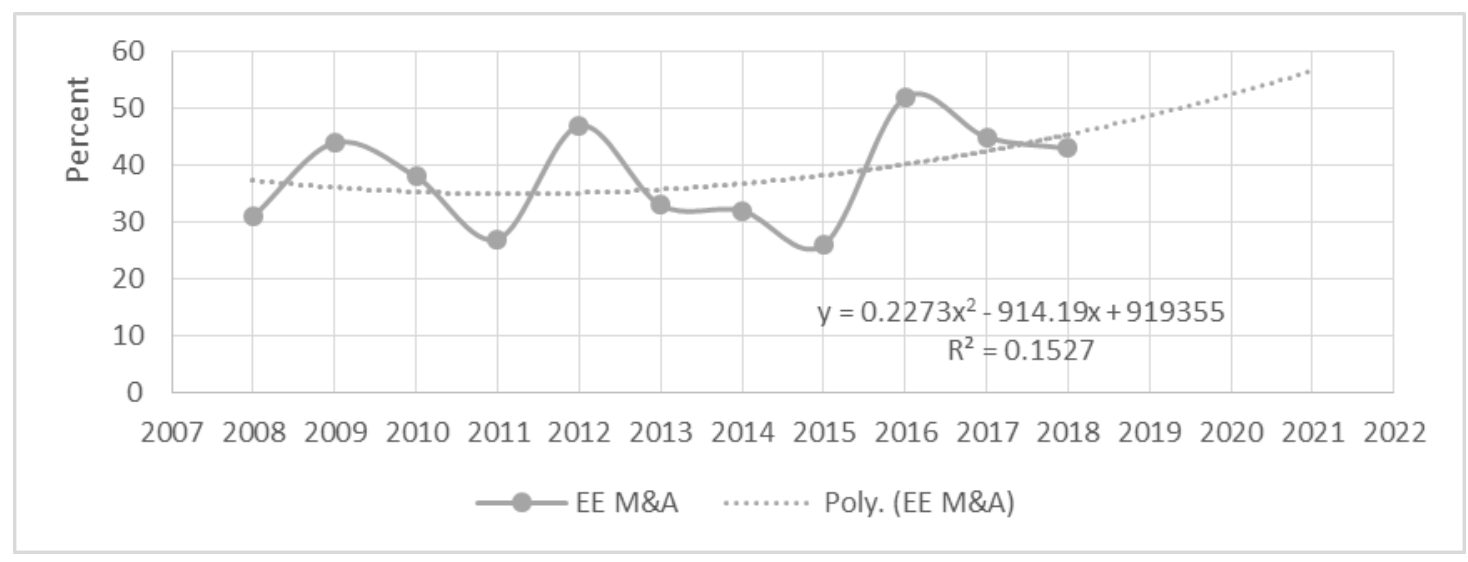

Figure 12. Forecast of mergers and acquisitions in Estonia applying a polynomial function (source: developed by the authors based on Baltic M\&A Monitor, 2019) 


\section{Conclusions}

Recently, the amount of global investment aimed at implementing merger processes has grown significantly. The practical significance of mergers has increased, both strategically and financially. The mergers and acquisitions market activity are often linked to various macroeconomic indicators. For the Baltic States, the year 2018 was exceptional in terms of corporate merger and acquisition (M\&A) deals, with the highest number of such deals recorded in the region. However, not only were their numbers increasing, but also their value, which increased compared to previous years. Gross domestic product growth in all three Baltic States, decreasing unemployment and rising consumption have all contributed to a spurt on the corporate M\&A market in the region.

Despite the unstable international environment, statistic data show that the year 2018 was a record year for the region. A US-based private equity fund, the Blackstone Group, acquired a majority stake in the Baltic bank Luminor, which was not only one of the largest deals in the region over the past decade but also a remarkable achievement for a relatively small market. This reflects the growing US interest in the Baltic States, and in recent years investors from China and the United Kingdom have been involved in increasingly highvalue deals. Mergers and acquisitions are taking place in the Baltic region also at the international level, where enterprises and funds from the Scandinavian countries are particularly active and the geographical range of investors is expanding.

A particularly large number of deals took place in 2017-2018 in the Technology, Media and Telecommunications (TMT) sector. The large number of M\&A offers in the sector indicates that the Baltic region is of interest to investors because of its considerable technological capacity. This sector remains the leading and most active sector with regards to deals in the region. In 2017-2018, TMT accounted for $17 \%$ of all deals, i.e., more than any other industry. However, the majority of these deals were relatively small in value and accounted for only $9 \%$ of the total value of the deals.

The Financial Services sector accounted for $7 \%$ of total deal volume during the period 20172018. The total value of deals increased from $6 \%$ in 2015-2016 up to 30\% in the last two years, including the Blackstone/Luminor deal. The deal is one of the largest in the Baltics and, according to Luminor, the bank will be able to expand its nextgeneration services. US investments in the sector dominated by Scandinavian banks infuse greater dynamism into the Baltic banking market.

The Energy, Mining and Utilities (EMU) sector has been quite active in recent years as a result of efforts to diversify energy resources and to restructure the utility sector, although the Baltic States are not particularly rich in natural resources. As regards the Industrials and Chemicals sector, although the economies of the three Baltic States are dominated by services sectors, the industry also has an important place in these economies, based on historical legacy and the rapid development of technology and foreign direct investment over the past three decades.

To see the future trends of the factors under consideration, forecasts of mergers and acquisitions (in percentage) and foreign direct investment are carried out in the Baltic States. The forecasts of mergers and acquisitions in the Baltic States using the weighted moving average method show that the highest percentage of all mergers and acquisitions is in Estonia, lower - in Lithuania and the lowest - in Latvia. The forecast of another important factor, namely, foreign direct investment, in the Baltic States using the weighted moving average method shows that Estonia's FDI has the highest value among all FDI in the Baltic States, which is followed by Lithuania's FDI, while Latvia's FDI has the lowest value.

Mergers and acquisitions in the Baltics were forecasted using various functions, such as exponential, linear, logarithmic, polynomial, power, etc. Upon analysing the outcomes of the mergers and acquisitions and their graphs according to various functions, the function with the highest coefficient of determination, and thus the highest correlation coefficient, was selected for forecasting. An analysis of the trends in mergers and acquisitions in the Baltics forecasted by applying a polynomial function shows that their outcomes are consistent with the forecasts carried out using the weighted moving average method, though trends appear less marked. To sum up, forecasts according to different methods project a future downward trend in the percentage of mergers and acquisitions (among the Baltic States) in Lithuania and Latvia and an upward trend - in Estonia.

\section{References}

Adams, S. (2008). Globalization and income inequality: Implications for intellectual property rights. Journal of Policy Modeling, 30, 725-735. https://doi.org/10.1016/j.jpolmod.2007.10.005 
Adam, A., \& Jacob, S. E. (2012). Consequences and possible solutions of financial crisis. Theoretical and Applied Economics, 12(577), 143-148.

Agrawal, A., \& Knoeber, C. R. (2012). Corporate governance and firm performance. In R. T. Christopher, W. F. Shughart (Eds.), Managerial economics. Oxford University Press.

https://doi.org/10.1093/oxfordhb/9780199782956. 013.0022

Alfaro, L., Chandab, A., Ozcanc, S. K., \& Sayekd, S. (2004). FDI and economic growth: the role of local financial markets. Journal of International Economics, 64, 89-112. https://doi.org/10.1016/S0022-1996(03)00081-3

Baliamoune-Lutz, M. N. (2004). Does FDI Contribute to economic growth? Knowledge about the Effects of FDI improves negotiating positions and reduces risk for firms investing in developing countries. Business Economics, 39(2), 49-56.

Baltic M\&A Monitor. (2019). https://www.acuris.com/baltic-ma-monitor-2019

Bazar, B., \& Sakar, A. N. (2011). Organization design and innovation: a comparative analysis of two corporations. International Journal of Business and Management Studies, 3(1), 67-79.

Bevins, V., Feeney, P., \& Jones, C. (2010). Mergers and acquisitions data 2000-2009. Journal of the Financial Times.

Blackstone Group. (2019). https://www.blackstone.com/

Brigham, E. F., \& Daves, P. R. (2012). Intermediate financial management (11th ed.). South-Western Cengage Learning.

Burkart, W. R., Klein, R., \& Mayer, S. (2012). Product line pricing for services with capacity constraints and dynamic substitution. European Journal of Operational Research, 219(2), 347-359. https://doi.org/10.1016/j.ejor.2011.12.026

Calderon, C., Loayza, N., \& Serven, L. (2004). Greenfield foreign direct investment and mergers and acquisitions - feedback and macroeconomic effects (Policy Research Working Paper. No. WPS 3192). World Bank.

https://doi.org/10.1596/1813-9450-3192

Campbell, J. Y., Hilscher, J., \& Szilagyj, J. (2008). In search of distress risk. Journal of Finance, 63, 2899-2939. https://doi.org/10.1111/j.1540-6261.2008.01416.x

Chatterjee, S. (2007). Why is synergy so difficult in mergers of related businesses? Strategy \& Leadership, 35(2), 46-52. https://doi.org/10.1108/10878570710734534

Choi, S. H., \& Jeon, B. N. (2011). The impact of the macroeconomic environment on merger activity: Evidence from US time-series data. Applied $\mathrm{Fi}$ nancial Economics, 21(4), 233-249. https://doi.org/10.1080/09603107.2010.528365

Cornett, M. M., McNutt, J. J., \& Tehranian, H. (2006). Performance changes around bank mergers: Reve- nue enhancements versus cost reductions. Journal of Money, Credit and Banking, 38(4), 1013-1050. https://doi.org/10.1353/mcb.2006.0053

De Pamphilis, D. M. (2010). Mergers, acquisitions, and other restructuring activities. Academic Press.

Deng, X., Kang, J. K., \& Low, B. S. (2013). Corporate social responsibility and stakeholder value maximization: Evidence from mergers. Journal of $\mathrm{Fi}$ nancial Economics, 110(1), 87-109. https://doi.org/10.1016/j.jfineco.2013.04.014

Doytch, N., \& Cakan, S. (2011). Growth effects of mergers and acquisitions: A sector-level study of OECD countries. Journal of Applied Economics \& Business Research, 1(3), 120-129.

Edwards, M. R., \& Edwards, T. (2013). Employee responses to changing aspects of the employer brand following a multinational acquisition: A longitudinal study. Human Resource Management, 52, $27-$ 54. https://doi.org/10.1002/hrm.21519

Fraser, D., R., \& Zhang, H. (2009). Mergers and longterm corporate performance: Evidence from crossborder bank acquisitions. Journal of Money, Credit and Banking, 41(7), 1503-1513. https://doi.org/10.1111/j.1538-4616.2009.00265.x

Gaughan, P. A. (2015). Mergers, acquisitions, and corporate restructurings $\left(6^{\text {th }} \mathrm{ed}\right.$.). John Wiley \& Sons.

Golbe, D. L., \& White, L. (2000). A time series analysis of mergers and acquisitions in the U.S. Economy. In A. Auerbach (Ed.), Corporate takeovers (pp. 265-305). University of Chicago Press.

Gruodis, P. (2009). Lithuania. In S. Robinson (Ed.), The mergers and acquisitions review (Chapter 36, pp. 343-350). Law Business Research Ltd.

Haleblian, J., \& Devers, E. C. (2009). Taking stock of what we know about mergers and acquisitions: A review and research agenda. Journal of Management, 35(3), 469-502. https://doi.org/10.1177/0149206308330554

Kolasa, M. (2008). How does FDI Inflow Affect Productivity of Domestic Firms? The role of horizontal and vertical spillovers, absorptive capacity and competition. The Journal of International Trade \& Economic Development, 17(1), 155-173.

https://doi.org/10.1080/09638190701728131

Kotane, T., \& Kuzmina-Merlino, I. (2012). Assessment of financial indicators for evaluation of business performance. European Integration Studies, 6, 216-224. https://doi.org/10.5755/j01.eis.0.6.1554

Lin, B. W., Hung, S. C., \& Li, P. C. (2006). Mergers and acquisitions as a human resource strategy: Evidence from US banking firms. International Journal of Manpower, 27(2), 126-142. https://doi.org/10.1108/01437720610666173

Lin, B., Lee, Z., \& Gibbs, I. G. (2008). Operational restructuring: Reviving an ailing business. Management Decision, 46(4), 539-552. https://doi.org/10.1108/00251740810865049 
Luminor Group. (2019).

https://www.luminor.lt/lt/luminor-groupdukterines-imones

M\&A Worldwide. 2019. https://m-a-worldwide.com/

Maček, A., \& Ovin, R. (2006). Cross-border mergers and acquisitions - a cause for growing economic nationalism? Business \& Economics Society International Conference, 2, 415-424.

Maček, A. (2012). A comparative analysis of the economic effects of cross-border mergers and acquisitions in european countries. Business, management and economics. In V. Bobek (Ed.), International trade from economic and policy perspective. IntechOpen. https://doi.org/10.5772/48342

Milichovsky, F., \& Simberova, I. (2015). Marketing effectiveness: Metrics for effective strategic marketing. Journal of Engineering Economics, 26(2), 211-219. https://doi.org/10.5755/j01.ee.26.2.3826

Mottaleb, K. A. (2007). Determinants of foreign direct investment and its impact on economic growth in developing countries.

http://mpra.ub.uni-muenchen.de/9457/1/MPRA_ paper_9457.pdf

Neto, P., Brandao, A., \& Cerqueira, A. (2008). The impact of FDI, cross-border mergers \& acquisitions and greenfield investment on economic growth (FEP Working paper, No. 291).
Parikh, V. (2011). Reasons for corporate restructuring. http://www.letslearnfinance.com/reasons-forcorporate-restructuring.html

Rhodes-Kropf, M., \& Viswanathan, S. (2004). Market valuation and merger waves. Journal of Finance, 59, 2685-2718. https://doi.org/10.1111/j.1540-6261.2004.00713.x

Roman, A., \& Rusu, D. V. (2011). Effects of the current economic crisis on small and medium enterprises sector in some EU member countries - a comparative study. International Journal of Business and Management Studies, 3(1), 333-342.

Rossi, S., Paolo, F., \& Volpin, F. P. (2004). Crosscountry determinants of mergers and acquisitions. Journal of Financial Economics, 74, 277-304. https://doi.org/10.1016/j.jfineco.2003.10.001

Tsang, M., \& Hauck, D. (2007). Stock markets contract as $M \& A$ overtakes equity sales. Blomberg, Jan 8.

Uddin, M., \& Boateng, A. (2011). Explaining the trends in the UK cross-border mergers \& acquisitions: An analysis of macro-economic factors. International Business Review, 20, 547-556. https://doi.org/10.1016/j.ibusrev.2010.11.003

Versli Lietuva. (2019). Imoniu susijungimai ir ìsigijimai [Mergers and acquisitions of enterprise]. https://enterpriselithuania.com/pleskis/imoniususijungimai-ir-isigijimai/ 